\title{
Article \\ On The Evaluation of Water Quality Index: Case Study of Euphrates River, Iraq
}

\author{
Omar Khaleefa ${ }^{1, *}$ and Ammar Hatem Kamel ${ }^{1}$ \\ ${ }^{1}$ Water resources Department, College of engineering, University Of Anbar, Iraq; ammar.kamel@uoanbar.edu.iq \\ * Correspondence: oma19e4007@uoanbar.edu.iq
}

Manuscript received: 08-08-2021, revised: 21-08-2021, accepted: 23-08-2021.

\begin{abstract}
This study is used the water quality index (WQI), which is generated by combining several water quality parameters. This index gives a helpful representation of overall water quality for the public and all intended applications, and it demonstrates that pollution is beneficial in water quality management and decision-making. The Euphrates River was assessed in order to determine the quality of drinking water. The Euphrates River was assessed for drinking water quality using the WQI, which includes ten physicochemical water quality criteria. This was achieved by submitting comprehensive physicochemical analysis of water samples collected from 5 stations in the city of Hit-Iraq during 2020-2021. The ten physicochemical parameters included: pH value, Nitrate $\left(\mathrm{NO}_{3}\right)$, Sulphate $\left(\mathrm{SO}_{4}\right)$, Turbidity, temperature, Calcium $(\mathrm{Ca})$, Magnesium $(\mathrm{Mg})$, sodium $(\mathrm{Na})$, electric conductivity (EC) and Total Dissolved Solids (TDS). This was accomplished by submitting a full physicochemical analysis of water samples obtained from 5 sites in Hit, Iraq, between 2020 and 2021. The results of the present study show, the total average WQI was 110,156. The high WQI achieved is caused by the high TDS and magnesium concentration due to the different human activities along the river reach. The Euphrates River quality is classified as 'very poor quality' with a minimum WQI of 97.85 in June and 121.75 in November.
\end{abstract}

Keywords: Euphrates River; Water quality index; Total dissolved solids; Water quality assessment.

\section{Introduction}

\subsection{Research background}

Rivers are the most significant natural resource for human development, but they are polluted by negligent sewage discharge, industrial waste, and a range of human activities, negatively impacting their physicochemical and microbiological quality [1], [2]. This could cause river water quality to deteriorate, necessitating the need to monitor water quality in order to determine the problem and its source [3], [4]. Water quality is a typical combination of physical, chemical, biological, and bacteriological elements given as numerical values that indicate the possibility for anthropoid usage of water [5]. For efficient management, it is critical to avoid and control river pollution and to have trustworthy water quality information [6], [7]. WQI identifies and compares water quality conditions over time, which are a variety of environmental indicators; assesses the efficacy of water quality management; raises awareness of general water quality issues; and indicates the necessity for and success of protective methods [8], [9]. There have been many efforts to make qualitative and quantitative water quality monitoring decisions over the literature [10]. In order to preserve public health and valuable fresh water resources, an extensive water quality monitoring program is increasingly needed. In order to gage the effects of unregulated discharges on river quality, the current study has been carried out with the objective of analyzing some selected water quality parameters for the Euphrates River. In addition, its adequacy for consumption on the basis of calculated WQI values is compared and discussed.

\subsection{Literature review}

The Water Quality Index (WQI) is a technique for converting vast volumes of water quality data into a single cumulative figure. It signifies a specific water quality while also removing subjective water quality ratings [11]. WQI is extremely useful for disseminating water quality information to the general public and providing a thorough understanding of the changing trend in water quality over time, as well as allowing comparisons across other rivers or locations within the same channel [12]. The WQI idea is based on comparing water quality parameters to regulatory criteria and generating a single value for a source's water quality; it turns a sample list 
of components and concentrations into a single value [13]. WQI on river had been reported by several researchers over the literature for instance, a study was conducted on landzu river, Nigeria for WQI assessment using APHA [14]. 120 experimental samples of physiochemical parameters were used for the modeling assessment. The research finding approved the deterioration of the river water quality as per the WHO. WQI of Euphrates River between Hit and Ramadi cities was using water quality parameter from November 2008 to June 2009. 12 water quality parameter .their found that the water quality of Euphrates river in the study area is "marginal "[15]. evaluate the quality of Euphrates River water for drinking usage. In this study, the WQI was indicated by summing up several parameters of the result of water tests. This was done by submitting comprehensive, physicochemical analysis of water samples from seven stations in the province of Al-Anbar from 2004-2010. The ten physicochemical parameters. From this analysis the quality of the Euphrates River is classified as "very poor quality" [16]. examines the spatial time variation of the Euphrates River Water Quality (WQI) index in the Governorate of Anbar. In 2018, water samples from nine stations have been collected. 15 parameters of water quality. The water quality is classified mainly as "significant" according to the mean value of WQI [17]. An attempt was made to develop the WQI using six parameters for water quality. It was found that high anthropogenic activities, illegal drainage of wastewater and industrial waste, lack of appropriate sanitation, unprotected river sites and urban flux were the main cause for deterioration in water quality [18]. Cauvery river water quality was monitored for three months in the district of Tiruchirappalli (January-March 2009). The WQI was considered to calculate these ten parameters. WQI shows that water from the River Cauvery is moderately polluted upstream of the city and not suitable for downstream consumption [19]. This study seeks to develop Iraq's water quality index (IRWQI), which can be used to assess the general water quality across the entire stretch of the main rivers (Tigris and Euphrates) of Iraq. This work's index consists of seven measurable parameters. The results show that the quality of water varied between very good and very bad [20]. A new WQI approach was developed in this study, depending on Iraqi drinking water specifications (IQS 417, 2009). Eight parameters were selected for water quality. The results showed that quality ranges from "Good" to "Poor" on the Euphrates River, enters Iraqi borders with "Good" water quality and gradually declines as soon as it receives pollution from many sources such as domestic sewage and various industrial waste until the quality of the river is "Poor" as per the classifications suggested [21]. The objective of this study was to evaluate Diwanyiah River water quality according to the Wasser Quality Index (WQI). Nine environmental parameters. Results have shown that river water quality ranges from poor to marginal [22]. This study aims mainly to assess for different purposes the Euphrates River in the city of Ramadi and in AlDhiban Canal. Results indicate that, in accordance with global and Iraqi standards, water in the Euphrates River in the city of Ramadi and the AlDhibán canal is suitable for drinking, irrigation and for various industrial purposes. This was above the allowed limits during the study interval for a few months, which led to additional restrictions for domestic and industrial purposes [23].

\subsection{Research objectives}

Due to the limited discharge in the Euphrates River, Iraq has experiences over the last ten year, the water quality of the river has experienced high deterioration all along the river locations. Hence, the current research was adopted for evaluating the WQI of the Euphrates River, Iraq. Five locations at Hit city, Anbar state, Iraq were selected for the water samples over five months, (November 2020-March 2021).

\section{Materials and Methods}

\subsection{Steady area Description}

River Euphrates is the longest river in the Middle East. The source lies between Lake Van and the Black Sea in Turkish eastern highlands. Roughly $40 \%$ of the river runs across Turquie, the remaining $25 \%$ in Syria and $35 \%$ in Iraq are divided between the two countries on the river [24], [25]. The Euphrates is a large Iraqi river, with drainage and access to the west side of the country. Naturally, flux fluctuations avoid the full potential of the river. Regrettably, the distribution of the water availability has no satisfaction with the basin's irrigation needs [26], [27]. The Euphrates River is a major river in Iraq with a drainage area and an entrance on the western side of the country. It runs on the Mesopotamian alluvial flat for approximately 337 kilometers in the region of AlAnbar. The climate is dry to semi-arid in this region with dry warm summers and cold winters. River water is used for irrigation and drinking water after purification. 
In an average year, during the winter months of April and May the river achieves its peak flow [28]. The normal low water season takes place in August and September, from July to December, and reaches its lowest value, when the winter crops in the region are most irrigated by the water. The average Euphrates monthly hydrograph shows variations in seasonal swings between 33 and 275 percent of the annual average (Iraqi Ministries of Environment, 2006).

\subsection{Water Quality Index (WQI)}

From November 2020 to March 2021, Samples were gathered from five locations located between Hit and Ramadi within Al-Anbar province. Fig. 1 shows the details on sampling sites. Several physico-chemical parameters were analyzed using the standard methods for the water samples. A set of ten parameters of water quality including $\mathrm{pH}$, electrical conductivity (EC), temperature, total solid dissolving (TDS), Turbidity, nitrate, sodium, magnesium and calcium River was selected for generating the index on water quality overall Euphrates WQI. WQI calculation was performed using the equation (1). The name of this method "The National Water Quality Foundation Index (NSFWQI)".

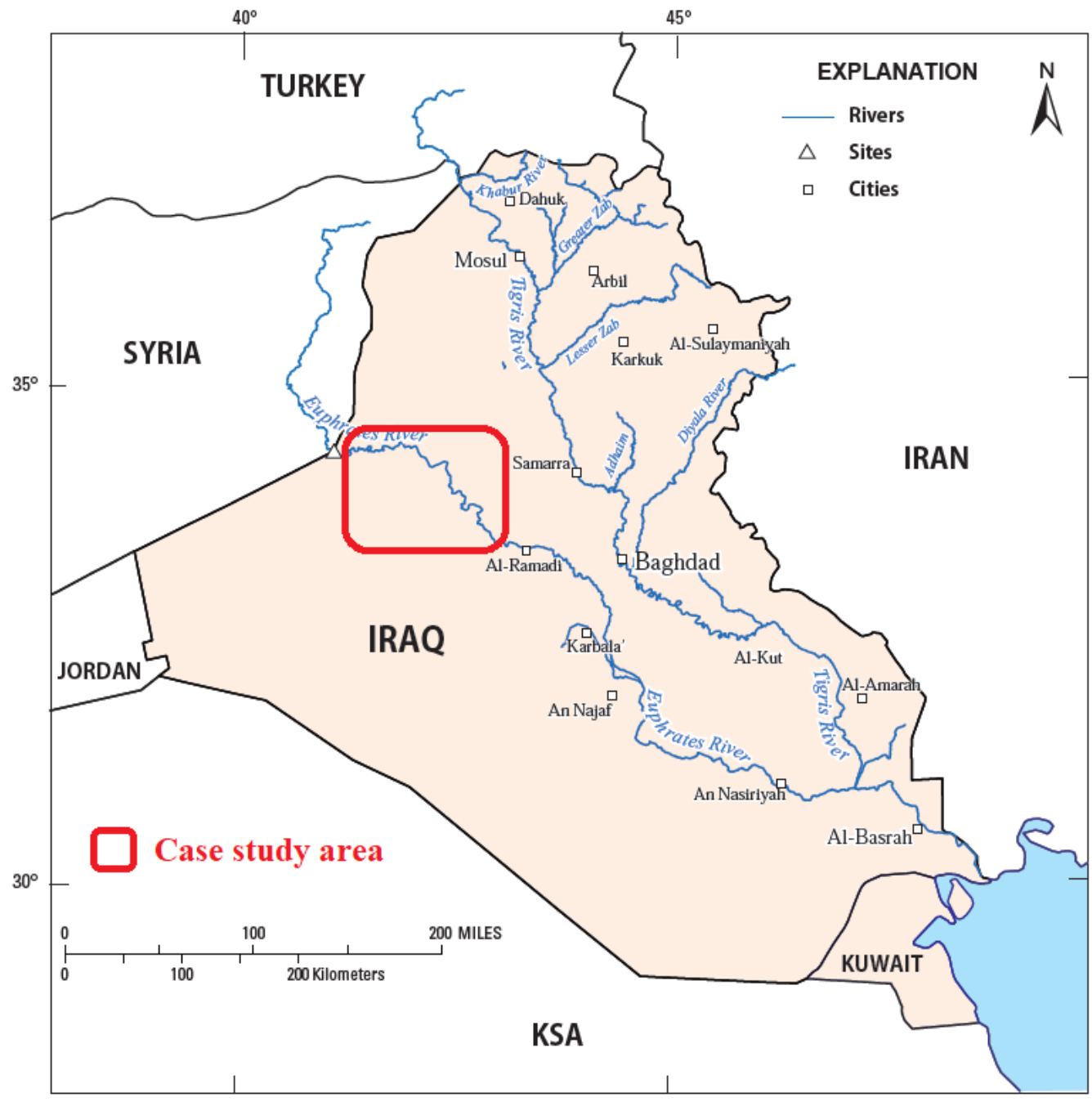

Figure 1. Euphrates River Basin and the location of the selected case study.

Based on the magnitudes of the water quality parameters, the WQI formula was applied and determined. In relation to their appropriateness of domestic usage and data availability at each station. These parameters were compared by the World Health Organization (WHO) on the basis of the WQI calculation format with allowable drinking water quality values: 


$$
W Q I=\sum_{i=1}^{n} w i * q i
$$

The unit weight (wi) for all the ten chosen parameters with standard values one given in Table 1.

The quality rating scale (qi) is a number reflecting the relative value of this parameter in the polluted water with respect to its standard permissible value and is determined as follows:

$$
q i=\frac{V i-V 10}{S i-V 10}
$$

The water quality rating is indicated by $(q i)$ for the $i^{\text {th }}$ water quality parameter $V i$ is presented the value of the estimated permissible. $V 10$ is defined the perfect value "ideal" for the $\mathrm{i}^{\text {th }}$ parameters in pure water. All the ideal values $(V 10=0)$ are taken as zero for drinking water except for $\mathrm{pH}=7.0$.

Table 1. Water Quality Parameters of WQI and their weight.

\begin{tabular}{|l|c|}
\hline Water Quality Parameters & Weights \\
\hline Dissolved oxygen & 0.17 \\
\hline Thermotolerant coliforms & 0.15 \\
\hline Hydrogen ionic potential - pH & 0.12 \\
\hline Biochemical oxygen demand - BOD5,20 & 0.10 \\
\hline Water temperature & 0.10 \\
\hline Total nitrogen & 0.10 \\
\hline Total phosphorus & 0.10 \\
\hline
\end{tabular}

Using the above laws and using the data available in the Table 2, the WQI was found for the parameters taken and for the time period.

Based on the calculated WQI, the classification of water quality types is shown in Table 3. The WQI was found for each month during the time period taken, where the results appeared as in Table 4.

\begin{tabular}{|c|c|c|c|c|c|c|}
\hline Parameters & $\begin{array}{l}\text { Standard } \\
\text { value (SI) }\end{array}$ & $\begin{array}{l}\text { Unit weight } \\
\text { factor (WI) }\end{array}$ & $V i$ & $V_{10}$ & $\begin{array}{c}\text { Quality } \\
\text { rating (qi) }\end{array}$ & WQI \\
\hline $\operatorname{Temp}^{\circ} \mathrm{C}$ & 15 & 0.1 & 22.36 & 0 & 149.06 & 14.906 \\
\hline pH & 7.5 & 0.074 & 8.60 & 7 & 320 & 23.68 \\
\hline TUR (NTU) & 5 & 0.08 & 6.3368 & 0 & 126.72 & 10.1376 \\
\hline TDS (mg/l) & 500 & 0.148 & 543.6 & 0 & 108.72 & 16.09 \\
\hline $\mathrm{EC}(\boldsymbol{\mu} \mathrm{s} / \mathrm{cm})$ & 780 & 0.08 & 1071.88 & 0 & 137.42 & 10.99 \\
\hline $\mathrm{NO}_{3}$ (mg/l) & 50 & 0.148 & 13.464 & 0 & 26.928 & 3.984 \\
\hline $\mathrm{SO}_{4}(\mathrm{mg} / \mathrm{l})$ & 250 & 0.148 & 220.04 & 0 & 88.016 & 13.026 \\
\hline $\mathrm{Na}(\mathrm{mg} / \mathrm{l})$ & 200 & 0.074 & 85.6 & 0 & 42.8 & 3.167 \\
\hline $\mathrm{Ca}$ (mg/l) & 100 & 0.074 & 47.18 & 0 & 47.18 & 3.491 \\
\hline $\operatorname{Mg}(\mathrm{mg} / \mathrm{l})$ & 30 & 0.074 & 43.322 & 0 & 144.4 & 10.685 \\
\hline Sum & & 1.00 & & & & 110.156 \\
\hline
\end{tabular}

Table 2. water quality parameter standards, assigned and unit weight and WQI calculated [29]. 
Table 3. monthly WQI variations along Euphrates River during 2020-2021.

\begin{tabular}{|c|c|c|c|c|c|c|c|c|c|c|c|c|}
\hline Months & $\begin{array}{c}\text { Wuality } \\
\text { classes }\end{array}$ & WQI & $\mathbf{M g}$ & $\mathbf{C a}$ & $\mathbf{N a}$ & $\begin{array}{c}\mathbf{S O}_{\mathbf{4}} \\
(\mathbf{m g} / \mathbf{l})\end{array}$ & $\begin{array}{c}\mathbf{N o} \\
(\mathbf{m g} / \mathbf{l})\end{array}$ & $\begin{array}{c}\mathbf{E C} \\
(\boldsymbol{\mu} \mathbf{s} / \mathbf{c m})\end{array}$ & $\begin{array}{c}\mathbf{T D S} \\
(\mathbf{M g} / \mathbf{l})\end{array}$ & $\begin{array}{c}\text { TUR } \\
(\mathbf{N T U})\end{array}$ & $\begin{array}{c}\mathbf{p H} \\
\mathbf{T e m p} \\
{ }^{\mathbf{0}} \mathbf{C}\end{array}$ \\
\hline $\begin{array}{c}\text { November } \\
2020\end{array}$ & 5 & 121.753 & 45.5 & 28.5 & 110 & 241 & 11.3208 & 1421.8 & 755 & 8.52 & 8.48 & 21.4 \\
\hline $\begin{array}{c}\text { January } \\
2021\end{array}$ & 4 & 97.852 & 50 & 35 & 86.5 & 192.4 & 10.143 & 1098 & 550.6 & 7.36 & 7.91 & 18.8 \\
\hline $\begin{array}{c}\text { February } \\
2021\end{array}$ & 5 & 120.227 & 29.11 & 113.4 & 81.543 & 335.8 & 4.48 & 1099.8 & 532.2 & 8.16 & 8.78 & 21 \\
\hline $\begin{array}{c}\text { March } \\
2021\end{array}$ & 4 & 99.88 & 47.5 & 20.5 & 74.5 & 164 & 4.9 & 879.8 & 440.4 & 4.798 & 8.824 & 24 \\
\hline $\begin{array}{c}\text { April } \\
2021\end{array}$ & 5 & 111.177 & 44.5 & 38.5 & 75.5 & 167 & 36.48 & 860 & 439.8 & 2.846 & 9.01 & 26.6 \\
\hline Mean & & & 43.322 & 47.18 & 85.6 & 220.04 & 13.46 & 1071.88 & 543.6 & 6.3368 & 8.6008 & 22.36 \\
\hline
\end{tabular}

Table 4: Water quality classification based on WQI value for drinking proposes [29].

\begin{tabular}{|c|c|c|}
\hline No. & WQI level & Water quality classification \\
\hline 1 & $0-25$ & Excellent \\
\hline 2 & $26-50$ & Good \\
\hline 3 & $51-75$ & Poor \\
\hline 4 & $76-100$ & Very poor \\
\hline 5 & More than 100 & $\begin{array}{c}\text { Unfit and unsuitable for } \\
\text { drinking }\end{array}$ \\
\hline
\end{tabular}

\section{Results and Discussion}

Table 2 shows the results of water quality for different parameters by taking the average for the sites. Table 3 shows the results of water quality for five months for different parameters by taking the average for the sites and comparing them with the standard values of drinking water. Table 4 shows the Water quality classification based on WQI value for drinking proposes.

The WQI was designed to allow comparisons of water quality between the various areas along the same river or among Iraqi rivers. Total sulphate value concentration was $220 \mathrm{mg} / \mathrm{l}$ indicating slightly lower than the permissible level for drinking water recommended $250 \mathrm{mg} / \mathrm{l}$, and the maximum value of sulphate in the river at Feb month. $\mathrm{pH}$ value concentration was 8.6 higher than the tolerable limits 7.5 , and the maximum value is at Apr month. Nitrate value $13.4 \mathrm{mg} / \mathrm{l}$ indicating that the nitrate concentration does not cause eutrophication in surface waters that still complies with the WHO recommendations $50 \mathrm{mg} / \mathrm{l}$, and the maximum value of nitrate in the river at Apr month. TDS concentration was $543.6 \mathrm{mg} / \mathrm{l}$ which is within the tolerable limits of $500 \mathrm{mg} / \mathrm{l}$, and the maximum value of TDS is at Nov month.

This may be due to the using of fertilizer in the region. The Turbidity concentration value was $6.33 \mathrm{mg} / \mathrm{l}$ which is found to be higher the permissible levels of $5 \mathrm{mg} / \mathrm{l}$ and the maximum value of Turbidity was located at November month which could be from a non-point pollution source. The total EC concentration value was $1071 \mathrm{mg} / \mathrm{l}$ and often higher than the permissible level recommended by the WHO for drinking water $780 \mathrm{mg} / \mathrm{l}$, and the maximum value of total EC in the river is at November. The mean concentrations of calcium and magnesium were 47.18 and $43.32 \mathrm{mg} / \mathrm{l}$ which are within the recommended permissible limit of $100 \mathrm{mg} / \mathrm{l}$ and $30 \mathrm{mg} / \mathrm{l}$ respectively. The maximum value of calcium and magnesium in the river were at February and January, 
respectively. Total sodium value was $85.6 \mathrm{mg} / \mathrm{l}$ which is lower than the maximum permissible limit in drinking water $200 \mathrm{mg} / \mathrm{l}$, and the maximum value of sodium was at Nov. Figure 2 shows the variation of the different water quality parameters along the selected stations on the Euphrates River.

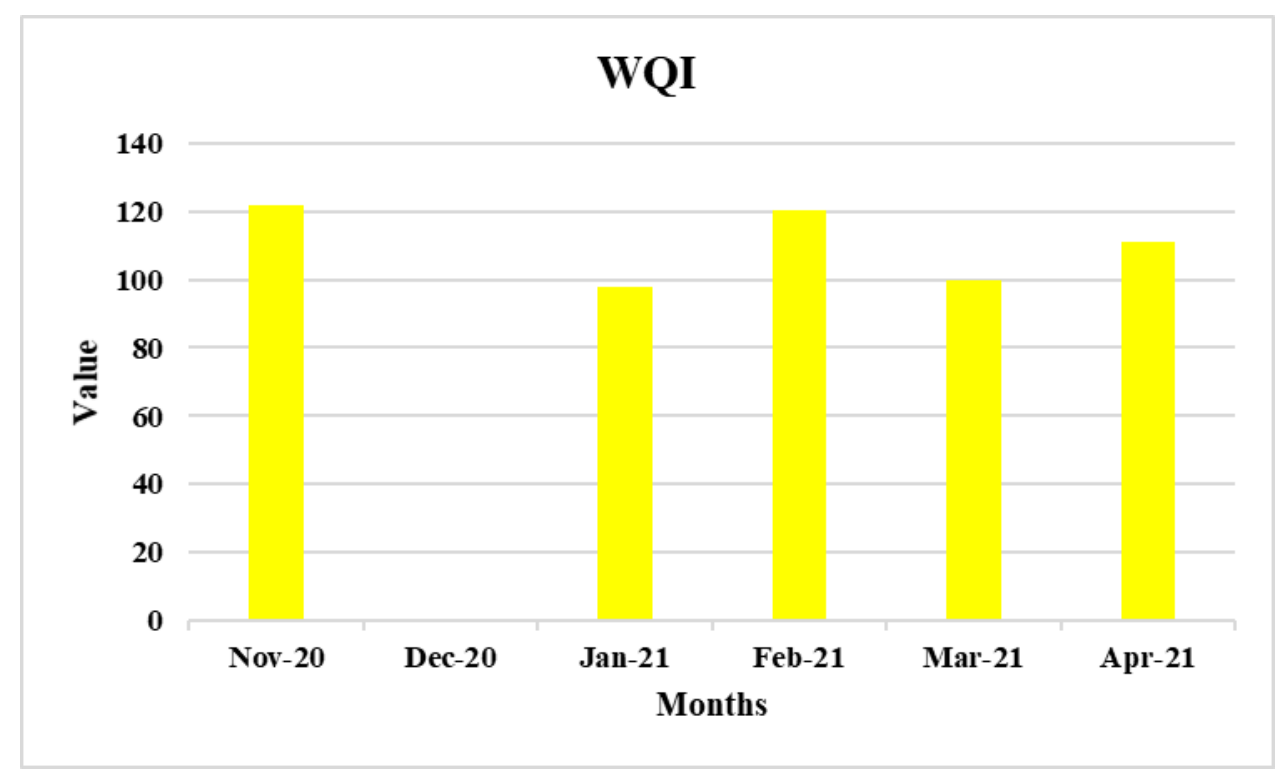

Figure 2. Variation of monthly mean values of WQI in Euphrates River within Al-Anbar province during 2020-2021.

The WQI on the Euphrates River in the province of Al-Anbar was calculated by ten raw water parameters in terms of suitability for human consumption, as compared with the World Health Organizations' recommended drinking water quality standards, using the assigned weighted arithmetic method (WHO, 2004). The water quality classification is shown in Table 3 based on the WQI value and the distribution by their quality groups of water samples. Water is classified into five classes according to WQI value, ranging from excellent water to very poor water. The calculated value of all Euphrates River samples and stations was 110.156, meaning that water is generally "unfit and not fit to drink," as indicated in Table 2 . The computed monthly overall WQI along Euphrates River for all samples. This implies that the water, as shown in Table 4, is generally "unfit for drinking". The monthly WQI variation ranged lower value 97.8 at January and higher value 121.75 in November along Euphrates River and classify from very poor water quality to Unfit and unsuitable for drinking. The results of this study show that the WQI of Euphrates River Water for all samples are not within the acceptable drinking water limit (100) which means contamination. The high value of WQI is due to the high phosphate and magnesium concentrations in the water and can be attributed to the various human activities on the banks of the river. Based on the reported literature [30], the authors carried out WQI inspection on the Euphrates River in 2012 to assess its anthropoid use such as potable and agricultural water uses, and the findings indicated that the quality of drinking and irrigation on the Euphrates River WQI varied from 'good' to 'very poor'.

To have better understanding for the water quality parameters measurements of the studied period, Figure 3 is generated. Worth to mention, December month was not measured due to some technical problem. The water temperature was measure $21.4^{\circ} \mathrm{C}$. Then after, there was a noticeable drop in the January month. The following three measured months indicated a substantial increment. The water temperature for specifically this region has different influential parameters "hydrological or climatological" and hence more future analysis for this parameter to be conducted. $\mathrm{Mg}, \mathrm{Ca}$, Turbidity and $\mathrm{pH}$ were reported almost alike trend except abnormal increase in $\mathrm{Ca}$ concentration and that can be explained either due to some human activities or some occasional experience that experience in the water chemical reaction. On the other hand, the $\mathrm{Na}, \mathrm{So}_{4}, \mathrm{EC}$ and TDS experienced decreasing trend by the early of 2021. This can be expected due to the weather changing as the winter is experienced those early months. The water physiochemical parameters were indicated some stochasticity and hence the WQI could be misleading of calculation due this variation. Hence, the implementation of the computer aid models can take place for this purpose as exhibited over the literature [31]. 


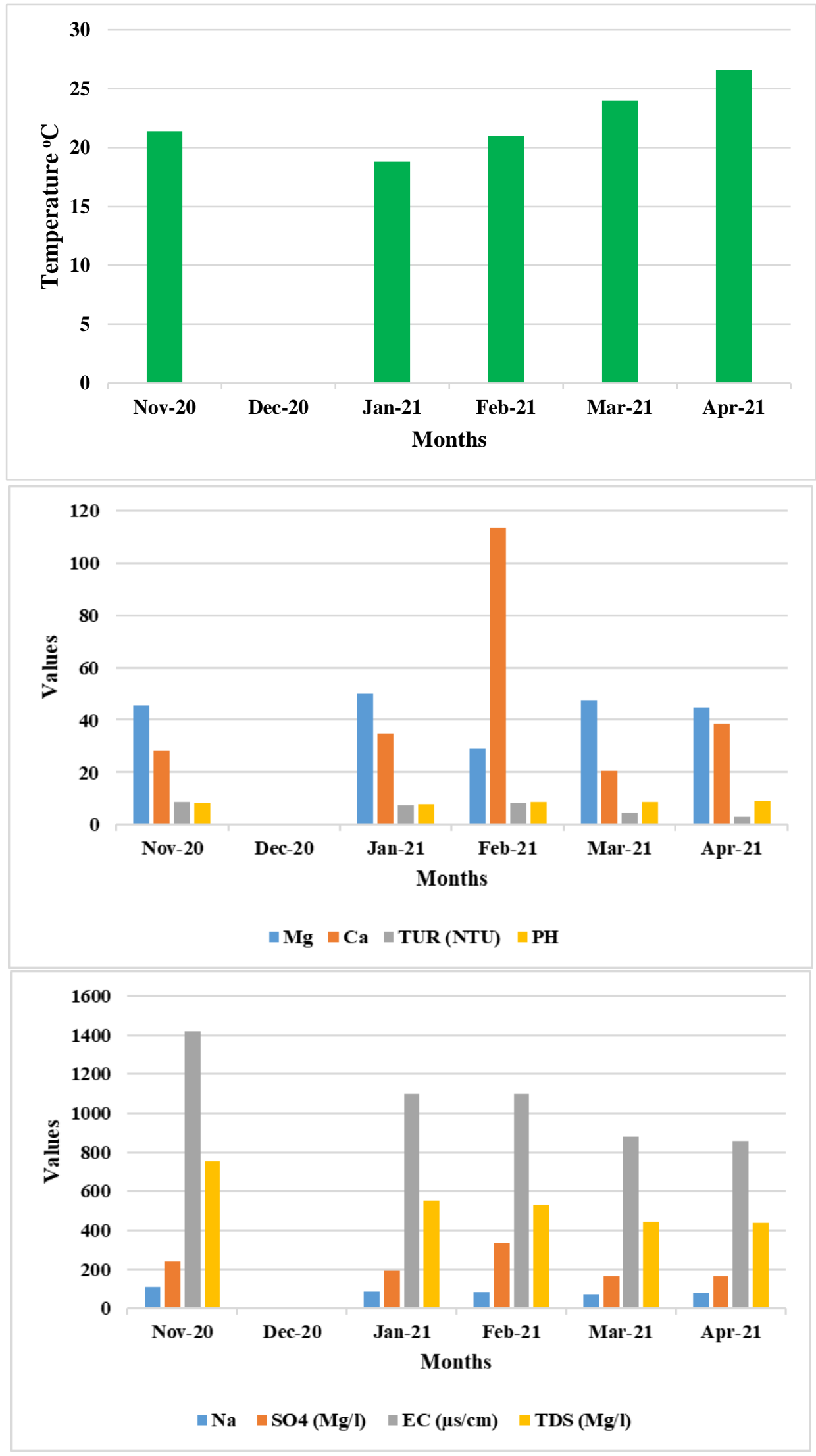

Figure 3. The trend of the water quality parameters over the studied period. 


\section{Conclusions}

WQI was found extremely useful for the evaluation of the overall water quality in this study. During the study period seven stations on the River Euphrates in Al-Anbar province have revealed that drinking water quality is not suitable. The results showed that the quality of the water of the Euphrates River was generally "very poor" and that the upstream water was poor and inappropriate for drinking, reflecting the impact of the pollution caused by the domestic and industrial wastewater sources. The WQI in determining the water quality in any river is consistent with current trends in water resources management, so that the classical physical and chemical parameters are given greater chemical and ecological significance. This method has numerous advantages because it contains only a number of more variables; it provides the same measuring unit with more parameters related to water quality; it gives the opportunity to compare the quality of more or a single water body in terms of time and space; and it provides a picture of water use in various ways fields or purposes.

Conflicts of Interest: The authors declare no conflict of interest

\section{References}

[1] W. H. M. Wan Mohtar, K. N. Abdul Maulud, N. S. Muhammad, S. Sharil, and Z. M. Yaseen, "Spatial and temporal risk quotient based river assessment for water resources management," Environ. Pollut., vol. 248, pp. 133-144, 2019.

[2] Z. M. Yaseen, M. M. Ramal, L. Diop, O. Jaafar, V. Demir, and O. Kisi, "Hybrid Adaptive Neuro-Fuzzy Models for Water Quality Index Estimation,” Water Resour. Manag., vol. 32, no. 7, pp. 2227-2245, May 2018.

[3] A. Mishra, A. Mukherjee, and B. D. Tripathi, "Seasonal and temporal variations in physico-chemical and bacteriological characteristics of River Ganga in Varanasi," 2009.

[4] Tiyasha, T. M. Tung, and Z. M. Yaseen, "A survey on river water quality modelling using artificial intelligence models: 2000-2020,” Journal of Hydrology. 2020.

[5] A. Kumar, B. S. Bisht, V. D. Joshi, A. K. Singh, and A. Talwar, "Physical, chemical and bacteriological study of water from rivers of Uttarakhand," J. Hum. Ecol., vol. 32, no. 3, pp. 169-173, 2010.

[6] R. Koklu, B. Sengorur, and B. Topal, "Water quality assessment using multivariate statistical methods_a case study: Melen River System (Turkey),” Water Resour. Manag., vol. 24, no. 5, pp. 959978, 2010.

[7] Z. M. Yaseen, M. Ehteram, A. Sharafati, S. Shahid, N. Al-Ansari, and A. El-Shafie, "The Integration of Nature-Inspired Algorithms with Least Square Support Vector Regression Models: Application to Modeling River Dissolved Oxygen Concentration," Water, vol. 10, no. 9, p. 1124, Aug. 2018.

[8] M. Hameed, S. S. Sharqi, Z. M. Yaseen, H. A. Afan, A. Hussain, and A. Elshafie, "Application of artificial intelligence (AI) techniques in water quality index prediction: a case study in tropical region, Malaysia," Neural Comput. Appl., pp. 1-13, 2016.

[9] T. M. Tung and Z. M. Yaseen, "Deep Learning for Prediction of Water Quality Index Classification: Tropical Catchment Environmental Assessment," Nat. Resour. Res., pp. 1-20, 2021.

[10] S. Randhawa, S. S. Sandha, and B. Srivastava, "A multi-sensor process for in-situ monitoring of water pollution in rivers or lakes for high-resolution quantitative and qualitative water quality data," in 2016 IEEE Intl Conference on Computational Science and Engineering (CSE) and IEEE Intl Conference on Embedded and Ubiquitous Computing (EUC) and 15th Intl Symposium on Distributed Computing and Applications for Business Engineering (DCABES), 2016, pp. 122-129.

[11] S. B. H. S. Asadollah, A. Sharafati, D. Motta, and Z. M. Yaseen, "River water quality index prediction and uncertainty analysis: A comparative study of machine learning models," J. Environ. Chem. Eng., 2020.

[12] R. Khan, A. Saxena, S. Shukla, S. Sekar, and P. Goel, "Effect of COVID-19 lockdown on the water quality index of River Gomti, India, with potential hazard of faecal-oral transmission," Environ. Sci. Pollut. Res., pp. 1-9, 2021.

[13] F. Khan, T. Husain, and A. Lumb, "Water quality evaluation and trend analysis in selected watersheds of the Atlantic region of Canada," Environ. Monit. Assess., vol. 88, no. 1, pp. 221-248, 2003.

[14] J. Yisa and J. O. Tijani, “Analytical studies on water quality index of river Landzu,” 2010.

[15] O. F. ANBAR, “ASSESSMENT OF THE WATER QUALITY INDEX OF EUPHRATES RIVER BETWEEN HEET AND RAMADI CITIES, IRAQ."

[16] A. S. Alsaqqar, B. H. Khudair, and A. A. Hasan, "Application of Water Quality Index and Water Suitability for Drinking of the Euphrates River within Al-Anbar Province, Iraq," J. Eng., vol. 9, no. 12, 2013. 
[17] W. M. Saod, E. A. M. S. Al-Heety, and M. M. Mohammed, "Spatial and temporal variation of water quality index of Euphrates River in Anbar Governorate, Iraq," in AIP Conference Proceedings, 2020, vol. 2213, no. 1, p. 20042.

[18] K. A. Shah and G. S. Joshi, "Evaluation of water quality index for River Sabarmati, Gujarat, India," Appl. Water Sci., vol. 7, no. 3, pp. 1349-1358, 2017.

[19] S. Kalavathy, T. R. Sharma, and P. Sureshkumar, "Water quality index of river Cauvery in Tiruchirappalli district, Tamilnadu," Arch Env. Sci, vol. 5, pp. 55-61, 2011.

[20] S. O. H. Al-Shujairi, "Develop and apply water quality index to evaluate water quality of Tigris and Euphrates Rivers in Iraq," Int. J. Mod. Eng. Res., vol. 3, no. 4, pp. 2119-2126, 2013.

[21] S. I. Mohammed and K. A. Abdulrazzaq, "Developing water quality index to assess the quality of the drinking water," Civ. Eng. J., vol. 4, no. 10, pp. 2345-2355, 2018.

[22] A. A. A. Abbas and F. M. Hassan, "Water quality assessment of Euphrates river in Qadisiyah province (Diwaniyah river), Iraq," Iraqi J. Agric. Sci., vol. 49, no. 2, pp. 251-261, 2018.

[23] A. S. Mustafa, "Evaluation of water quality parameters in the Euphrates river within Ramadi city and Al-Dhiban canal," J Al-Anbar Univ Pure Sci, vol. 3, no. 2, pp. 39-48, 2009.

[24] A. S. Mustafa, S. O. Sulaiman, and K. M. Al_Alwani, "Application of HEC-RAS Model to Predict Sediment Transport for Euphrates River from Haditha to Heet 2016," J. Eng. Sci., vol. 20, no. 3, pp. 570-577, 2017.

[25] A. M. Noon, H. G. I. Ahmed, and S. O. Sulaiman, "Assessment of Water Demand in Al-Anbar Province- Iraq," Environ. Ecol. Res., vol. 9, no. 2, pp. 64-75, Apr. 2021.

[26] A. B. A. Najm, I. M. Abdulhameed, and S. O. Sulaiman, "Water Requirements of Crops under Various Kc Coefficient Approaches by Using Water Evaluation and Planning (WEAP)," Int. J. Des. Nat. Ecodynamics, vol. 15, no. 5, pp. 739-748, Nov. 2020.

[27] S. O. Sulaiman, G. Al-Dulaimi, and H. Al Thamiry, "Natural Rivers Longitudinal Dispersion Coefficient Simulation Using Hybrid Soft Computing Model," 2018 11th International Conference on Developments in eSystems Engineering (DeSE). IEEE, 2018.

[28] S. O. Sulaiman, A. S. Mustafa, and O. M. Hussein, “Application of SWAT Model for Sediment Loads from Valleys Transmitted to Haditha Reservoir,” J. Eng., vol. 22, no. 1, 2016.

[29] S. L. Dwivedi and V. Pathak, "A preliminary assignment of water quality index to Mandakini River, Chitrakoot," Indian J. Environ. Prot., vol. 27, no. 11, p. 1036, 2007.

[30] S. A. M. Alhashimi and A. S. Mustafa, "Prediction Of Water Quality Index For Euphrates River, Iraq," Int. J. Environ. water, vol. 1, no. 2, pp. 114-128, 2012.

[31] S. I. Abba et al., "Evolutionary computational intelligence algorithm coupled with self-tuning predictive model for water quality index determination," J. Hydrol., vol. 587, p. 124974, Aug. 2020. 